研究

ほう化合金粉末と Ni 粉末を添加した Mo 圧粉体の焼結挙動

坂本卓

八代工業高等専門学校, $\bar{\top} 866$ 八代市平山新町 2627.

\title{
Behaviors of Mo Powder Compacts with an Addition of Boride Alloy Powders and Ni Powder
}

\author{
Takashi Sakamoto
}

Department of Mechanical Engineering, Yatsushiro National College of Technology, 2627 Hirayama-shinmachi, Yatsushiro 866.

Receved January 19, 1993

We studied the sintering behavior of Mo powder compacts with an addition of boride alloy powders and $\mathrm{Ni}$ powders. These boride alloys are $\mathrm{CrB}, \mathrm{TiB} 2$ and $\mathrm{WB}$ which have high decomposition temperature. The results of this experiment are as follows: 1)Though relative densities of sintered Mo powder compacts with an addition of boride alloy powders slightly rise up, these boride alloy powders do not disintegrate at sintering temperature.

2)The liquid phase produces in matrices of Mo powder compacts with supplementary addition of $\mathrm{Ni}$ powder at sintering temperature and promotes the densification.

3)Two endothermic peaks in DTA curve denote points of liquid phases. We infer that the endothermic peak at low temperature side is the transient liquid phase, because the liquid phase produces temporarily at parts of the matrix in heating up to melting point. The other endothermic peak corresponds to the melting point of Mo powder compact.

4) WB alloy powder in Mo powder compacts with an supplementary addition of Ni powder decomposes at lower temperature than that of WB boride compound.

1 緒 言

Mo粉末の焼結に際してBを微量添加した圧粉体は著 しい活性化を示し，ち密化する”。またBの化合物の 1つであるB 4 C粉末をMo压粉体の表面から拡散浸透さ せたとき，高い硬さを得ることができだ'がこれ
はB 4 C粉末が分解するとともにBのMoへの搪散，およ

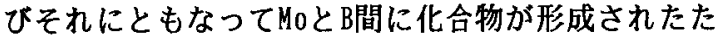
めである。さらにB $B_{4} C$ 粉末をM0粉末に直接添加し，粉 末間の界面を增して焼結した場合には， $B_{4} C$ 化合物固 有の分解温度より低い温度において分解してMo-B系 
末間の界面を増して焼結した場合には， $\mathrm{B}_{4} \mathrm{C}$ 化合物固 有の分解温度より低い温度において分解してMo-B系 の化合物を形成した。しかし, $\mathrm{B}_{4} C$ 粉末単味の添加で はち密化がわずかであったため, 同時にNi粉末を添 加して $B_{4}$ C粉末の挙動を調べたところ, NiとBとの間 で共晶が生成し液相を生じた。この液相は, $\mathrm{B}_{4} \mathrm{C}$ 粉末 だけ添加して高い温度で焼結しても生じなかったが, $\mathrm{Ni}$ 粉末を添加することにより, それより低い焼結温 度において出現するとともに，Mo圧粉体のち密化に

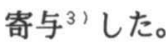

一方, Mo と他の元素類の 2 元状態図から調べると, Cr，TiおよびWはMoに全率固溶する4)ため,これらの 粉末を添加した場合に, Mo粉末の焼結に際して活性 化を示すことを期待して，ち密化するかどうかを調 ベたが, 焼結密度の向上は少なかった ${ }^{5)}$ 。

そこで本研究は, 全率固溶するこれらの 3 種類の 元素をBと合金化させ, その化合物を粉末としてMo圧 粉体に，また同時に $\mathrm{B}_{4} \mathrm{C}$ 粉末の添加の際に効果がみら れた $\mathrm{Ni}^{3)}$ をM0圧粉体に添加して焼結の挙動を調べた。 また高い硬さを得るなどの目的で，Mo-Ni圧粉体に種 々の炭化物を添加して液相下で焼結した研究も報告 されている(6)ため, ほう化合金粉末に同時にNi粉末 を添加することは, 焼結温度と相の変化の関係に影 響するかを知見することを含んでいる。3 種類のほ う化合金はいずれも分解温度が $2000^{\circ} \mathrm{C}$ 以上と高 温になる7'ためこれらを選んだ，このような化合 物の粉末をMo圧粉体に添加した場合に, それより低 い焼結温度域で分解してち密化に寄与するかどうか をE P M AおよびS E M 観察によって調べた。

\section{2 実 験 方 法}

実験に使用した粉末は母粉を純Mo粉末 (平均粒径 4. $32 \mu \mathrm{m}$ : 日本タングステン社製）とした。また 添加粉末には 3 種類のほう化合金粉末およびカーボ ニル Ni粉末 (Inc0社製: 123 型, 平均粒径 $4 \sim 7 \mu \mathrm{m}$ ) を選んだ。ほう化合金粉末はいずれも市販品の機械 破砕したCrB合金粉末 (平均粒径 $9.70 \mu \mathrm{m}, \mathrm{B}$ 含有 量 $17.72 \mathrm{wt}$ ) , $\mathrm{TiB}_{2}$ 合金粉末 (以下同じく 3 . $91,31.28$ ) およびWB合金粉末 ( $3.59,5$. 51 ) である。これらの粉末の外観をPhoto.1に示す。 外観形状は 3 種類の粉末とも角張った異形の粉末で あり，とくにTiB 2 粉末およびWB粉末は粒子がきわめ て小さく部分的に凝集していることがわかる。 Mo粉末にほう化合金粉末を $0 \sim 10 \mathrm{wt} \%$, Ni 粉末を

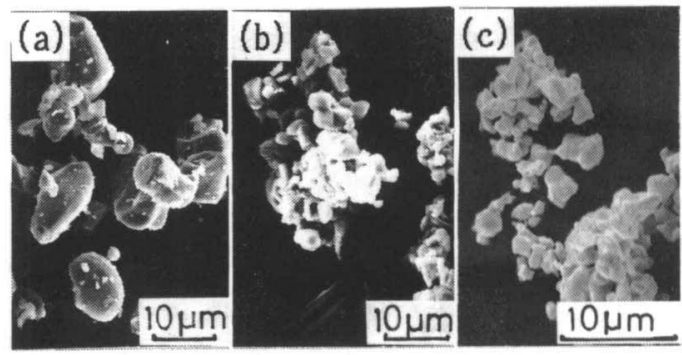

Photo.1 Appearance of boride alloy powders. (a):CrB alloy powder, (b):TiB 2 alloy powder, (c):WB alloy powder.

0〜 5 wt\%添加して乳鉢で入念に混合した。つぎにエ タノール溶液中にステアリン酸Znを溶かした潤滑剤 を塗布した金型を用いて，加圧力490MPaで単軸方 向に圧粉し $\phi 11.28 \mathrm{~mm}$ の柱成形体を作製した。 これを真空雾囲気中 ( $10^{-3}$ Torr 以下) で, 温度 8 $00{ }^{\circ} \mathrm{C} \sim 1400^{\circ} \mathrm{C}$ 3. $6 \mathrm{Ks}$ 保持して焼結し, 焼 結前後の寸法変化およひ相対密度を測定した。

つぎにほう化合金粉末およびNi粉末の, Moとの界 面における挙動を観察するためE P M A (加速電圧 : $20 \mathrm{KV}$,試料電流：0.05 0 A) により面分析した。 また焼結の進行と焼結温度との関係さらにはほう化 合金粉末の界面における挙動を確認するため D T A (示差熱分析:リガク製:TAS200型) を行った。D T $\mathrm{A}$ は同じ加圧力で圧粉したNi粉末添加のMo圧粉体を Arガス需囲気中で $0 \sim 1400^{\circ} \mathrm{C}$ まで昇温速度 20 ${ }^{\circ} \mathrm{C} \cdot \mathrm{min}^{-1}$ で加熱して熱変化を読み取り, 曲線から液 相点を求めた。

さらに焼結体は破断したあと, その破面を S E M により観察して組織および焼結の促進を調べた。

\section{3 実験結果および考察}

Mo圧粉体にそれそれ 3 種類のほう化合金粉末を添 加して焼結したときの相対密度をFig.1に示す。単味 のMo圧粉体を $1300^{\circ} \mathrm{C} て ゙$ 焼結したときの相対密度 は $74.4 \%$ あるる。相対密度はCrB合金粉末を 0 . 2 wt\%とわずかに添加することにより向上し， 79 . $6 \%$ の゚ークを示したあとは添加の増量とともに低下 する。 $\mathrm{TiB}_{2}$ 合金粉末の場合は添加によって殆と向上 しない。一方WB合金粉末は $1 \mathrm{wt} \%$ 添加量まで漸増し， $80 \%$ 達したあとは添加量の增加とともに低下して いくがわずかであり， $5 \mathrm{wt} \%$ 添加でも $78.8 \%$ 
保ち，3 種類の合金粉末の中では相対密度の向上に 関して最も効果があった。しかし，いずれにしても 3 種類のほう化合金粉末の添加によっては相対密度 はわずかな上昇にとどまり，焼結温度を $1400^{\circ} \mathrm{C}$ に向上しても（後述Fig.2）急激な相対密度の向上は 期待できなかった。

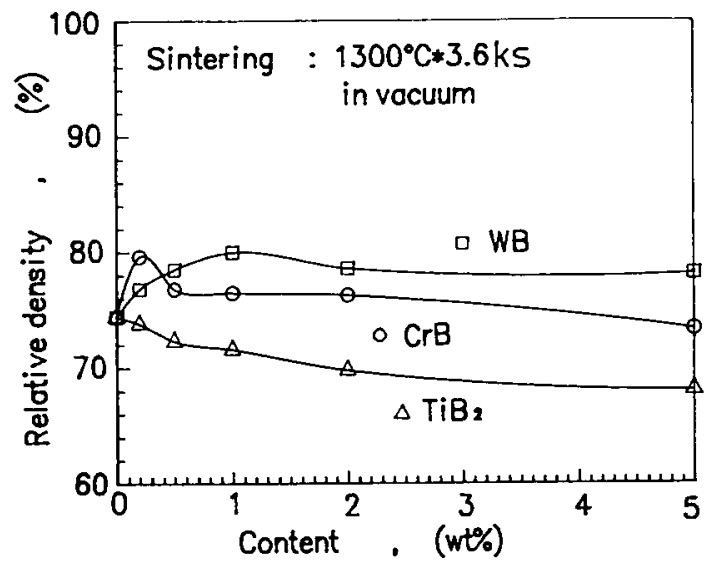

Fig.1 Relation between relative densities and boride alloy powder contents.

相対密度の上昇がわずかであったことは，ほう化 合金粉末がまだこの程度の焼結温度では分解が少な く，Mo粉末との界面における反応（とくにBとの）が わずかであると思われる。そこでBA $C$ 粉末を添加した Mo压粉体の相対密度の向上に際して，同時にNi粉末 を添加した結果”を参考にして，同しようにNi粉末 を添加した場合に相対密度の向上，そのときのほう 化合金粉末の分解あるいは饷との反応などが観察で きるかどうか, 焼結密度と焼結の促進過程さらに界 面における各元素の挙動を探った。

まず 3 種類のほう化粉末は, 挙動を確認し易くす るためを添加量を多くそれてれ単味で 10 wt\%添加し た場合と，Ni粉末を同時に $5 \mathrm{wt}$ 追加して添加した場 合の $2 つ の$ 圧粉体について焼結した。これらの圧粉 体を各温度で焼結した場合の相対密度をFig.2に示す。 Ni粉末の添加がないとき（白点）の3種類のほう化 合金粉未の相対密度は，焼結温度の上昇にともない， WB合金粉末の場合が向上しているが，CrB合金粉末お よびTiB 2 合金粉末の場合はむしろ低下する。それで

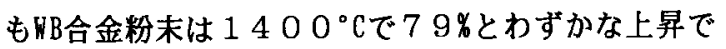

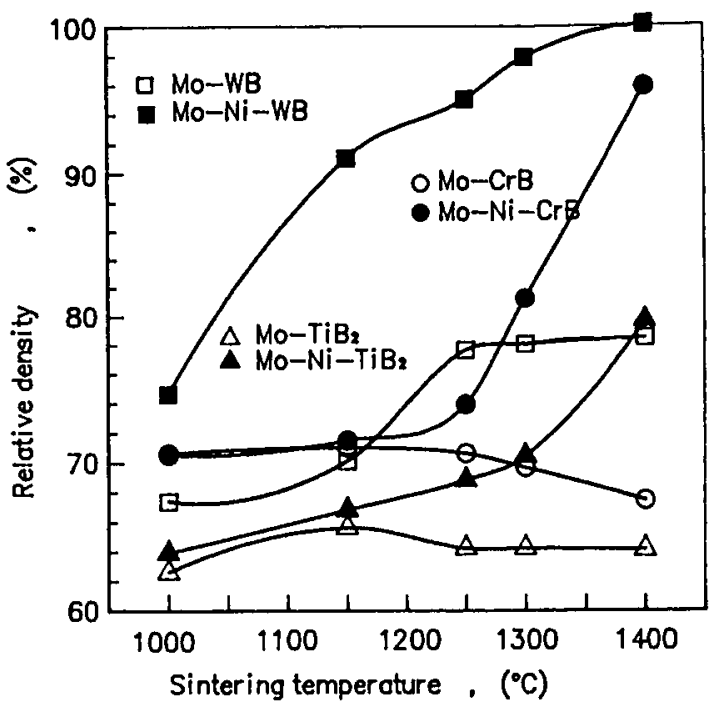

Fig.2 Relative densities of Mo powder compacts with an addition boride alloy powder and with supplementary addition of $\mathrm{Ni}$ powder at each sintering temperatures.

あつた。Ni粉末を添加した場合（黒点）の相対密度 は, 焼結温度の上昇とともに 3 種類の合金粉末いず れの場合においてもよく向上している。なかでもWB 合金粉末は $1150^{\circ} \mathrm{C}$ 方急激に上昇し $1300^{\circ} \mathrm{C}$ で97.9\%，1400 Cで100\%に達した。すな わちNi粉末を同時に添加することにより著しい変化 が生じることがわかる。

3 種類の合金粉末はNi粉末を同時に添加した場合 においても焼結温度の高低によって相対密度にかな り差異がある。このことは, おそらく焼結時にほう 化合金粉末が分解し，そのためち密化が促進される。 さらに 3 種類のほう化合金粉末はそれそれ分解温度 に差異があると思われる。そこで，各焼結温度にお ける焼結体をE P M Aにより面分析した。この結果 ではほう化合金粉末を単味で添加した場合は，3種 類の合金粉末とも殆ど分解がみられなかった。しか しつきにそれそれにNi粉末を同時に添加した場合 は全く異なる結果が生じた。その結果をPhoto.2,3に 示す。

Photo.2はCrB合金粉末およびTiB 2 合金粉末を添加 して $1400^{\circ} \mathrm{C} て ゙$ 焼結したときの各特性線像と S E M像である。CrB合金粉末およびTiB 2 合金粉末の場合 ともそれそれCr】 $\alpha$ 線像およびTiK $\alpha$ 線像にNiK $\alpha$ 線像 
Mo -5 wt\$Ni -10 wt\$CrB, Mo- 5 wt\$Ni -10 wt\$Ti B 2

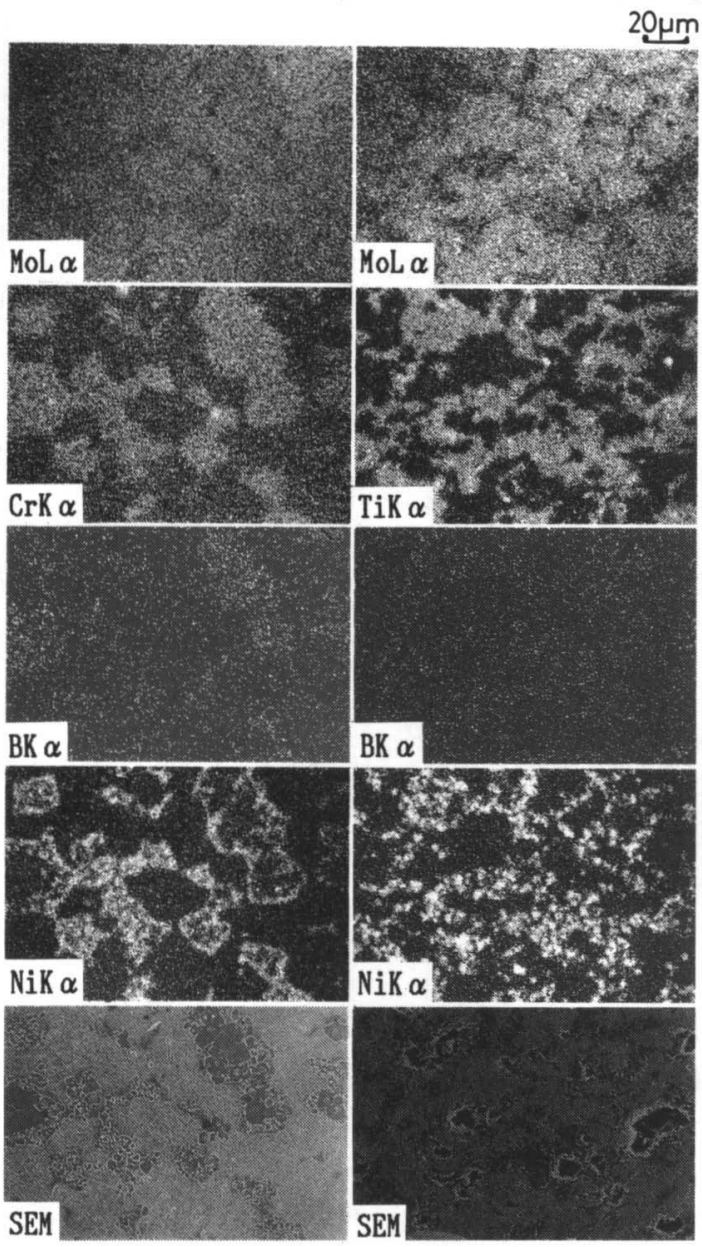

Photo.2 EPMA micrographs of Mo-5wt\%Ni-10wt\%CrB powder compact and Mo-5wt\%Ni-10wt\%TiB powder compact sintered at $1400^{\circ} \mathrm{C}$ for $3.6 \mathrm{ks}$.

が重なっていることから, 両合金粉末はNi粉末とよ く親和していると考えられる。またBk $\alpha$ 線像はCrK $\alpha$ 線像およびTiK $\alpha$ 線像との間でわずかであるが相関が

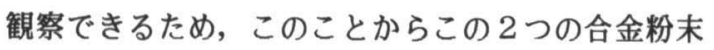
の分解は始まっていない。1300 ${ }^{\circ} \mathrm{C}$ 以下の焼結温 度においてはCrK $\alpha$ 線像およびTiK $\alpha$ 線像が 1400 。Cのときと較べてなお明瞭であり,これらの特性線 像とNiK $\alpha$ 線像との相関もない。つぎに S E M 観察に よると明らかに液相を確認することができる。とく にCrB合金粉末の場合はマトリックス中に丸みを帯び た粒子が凝集し，この輪郭が NiK $\alpha$ 線像と相関してい
るため, $\mathrm{Ni}$ 粉末が溶融して液相を生じたものと思わ れる。液相の出現は 2 つの合金粉末とも $1300^{\circ} \mathrm{C}$ で焼結した場合にもわずかに確認することができた。 Fig.2に示したように, $1300^{\circ} \mathrm{C}$ さらは 1400 。Cの焼結温度で相対密度がいずれも急激に上昇して いることは，上に述べたように各特性線像と S E M 観察の結果から，それそれの合金粉末が分解して焼 結を促進したものとは思われず，むしろNi粉末によ る液相の出現が影響していると推察される。

つぎにPhoto.3はWB合金粉末の場合で, 1250 ○ Cおよび $1300^{\circ}$ Cで焼結したときの各線像と S E M を示す。まず 1250 ○CではWL $\alpha$ 線像が全面に小さ い点状に散らばってみられるため, BK $\alpha$ 線像との関 連は認めにくいがまだWB合金粉末の分解は始まって
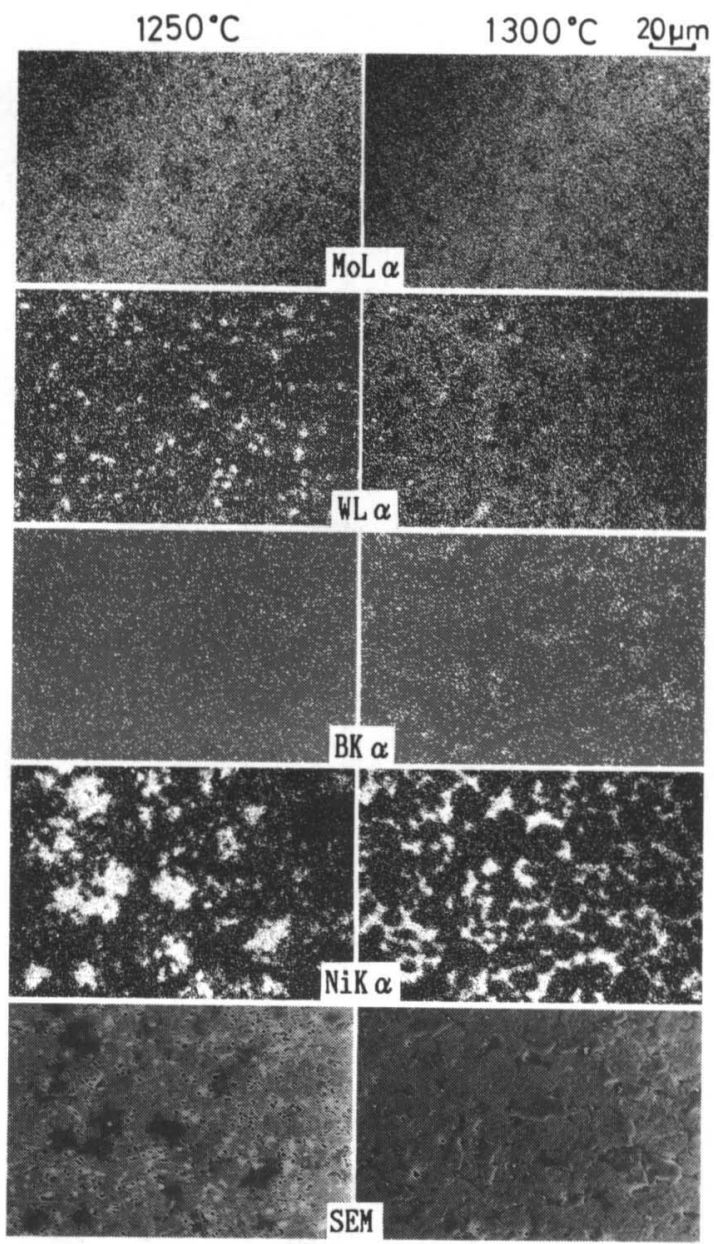

Photo.3 EPMA micrographs of Mo-5wt\%Ni-10wt\%WB powder compact sintered at $1250^{\circ} \mathrm{C}$ and $1300^{\circ} \mathrm{C}$ for $3.6 \mathrm{ks}$. 
いないと思われる。これは $1250^{\circ} \mathrm{C}$ 未渵の焼結温 度でも同じ傾向である。S E Mを観察すると微少な 気孔が数多く確認でき液相はみられない。Fig.2に示 した相対密度は, 固相焼結と思われるこの温度にお いてすでに $95 \%$ 極めて高い。これは明らかにNi粉 末添加による効果であるが，M0圧粉体にNi粉末を 5

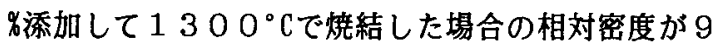
$3 \%$ 程度である゙うことから，相対密度の向上はNi粉末 添加だけによる影晋とは考えられない。上に述べた ようにCrB合金粉末およびTiB 2 合金粉末が $1400^{\circ}$ てでもまた分解が始まっていないと思われたのに対し，

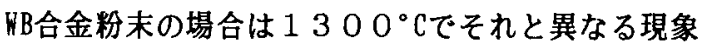
が観察された。すなわちWL $\alpha$ 線像は $1250^{\circ} \mathrm{C}$ と比 較しても明暸であるように小さく分散しているため, WB合金粉末が分解していると考えられる。またNiK $\alpha$ 線像はWL $\alpha$ 線像と相互に関連していない。むしろS E M 観察によると粒子が成長し，粒子の外形が丸み を帯びている。これは明らかに液相の出現である。 そのため気孔は液相の出現によって粒子内部に閉じ 込まれ球状を呈している。このように相対密度の向 上は液相による効果と思われる。

以上のように相対密度の向上は，おもにNi粉末の 添加によって生じる液相焼結によって促進されると 推察されるが， 3 種類のほう化合金粉末を比較する とWB合金粉末が他に比較して低い焼結温度で分解が 進むことがわかる。また液相の出現については上に 述べたように，他の 2 つのほう化合金粉末も焼結温 度 $1300^{\circ} \mathrm{Cで}$ 観察することができた。しかしこれ らの合金粉末は, 焼結に際して液相が出現してもち 密化の効果が少なく相対密度が低いこと。さらに液 相下でも合金粉末の分解が観察されないことがWB合 金粉末と異なっていることがわかる。

そこで上に述べた相対密度の結果および E P M A による考察を, 厌粉体の蛄結過程における熱変化か ら検討することとし，Ni粉末を同時に添加した 3 種 類の合金粉末をD T Aにより調查した。その結果の うち $1150^{\circ} \mathrm{C} \sim 1400^{\circ} \mathrm{C}$ 間におけるD T A曲線 をFig.3に示す。3つの曲線は白丸および黒丸で示す 2 箇所に大小の吸熱のビークがある。吸熱を示す場 合は一般に物理的変化として結晶転移，溶融あるい は蒸発, 化学的には脱水あるいは還元なとが生じる とされている。そこでこのピーク前後で焼結した試 料をX線回折したところ，結晶転移あるいは罢元の 現象は認められなかったため，この白丸で示す吸熱

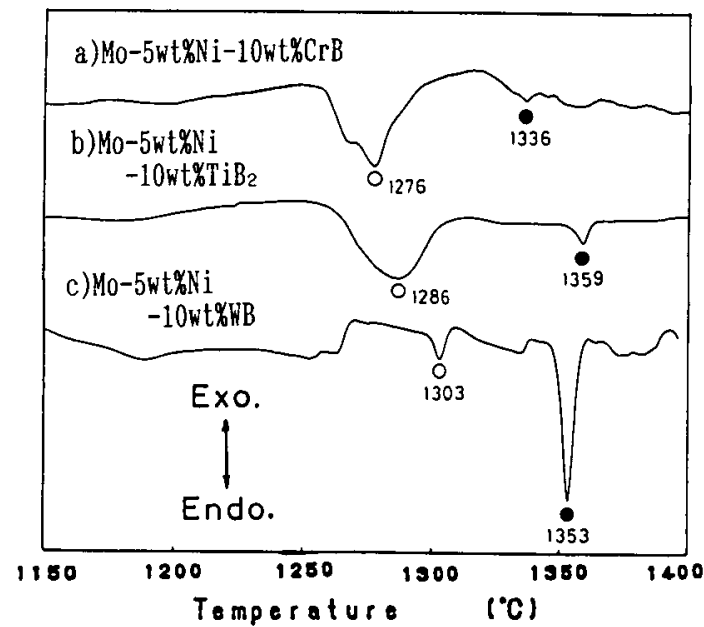

Fig. 3 DTA curves of Mo powder compacts with an addition of $5 \mathrm{w} t \mathcal{X}$ boride powder and 10wtX $\mathrm{Ni}$ powder.

ピークは溶融，すなわち液相が出現したために生じ たものと推測した。つぎ同じように黒丸で示す吸 熱のピークは夜相が出現した温度よりなお高温部で 生じているため判断が難しいが，この吸熱ピークは マトリックスの全体的な溶虽を示すものであると思 われる。すなわち白丸で示す低温側の吸熱ピークは, 黒丸部の高温側で溶融が起こる前に，わずかな液相 がマトリックス中の局部に生したものであり，遷移 的液相 ${ }^{8.91}$ と称される一時的な液相の出現であると 推察する。白丸部のそれそれの 3 つの圧粉体を 13 $00^{\circ} \mathrm{C} て ゙$ 焼結したときのS E M 観察によっても液相 が確認されたことから，白丸部の吸熱ピークはやは り液相の出現である。またCrB合金粉末およびTiB 2 合 金粉末の場合の $1400^{\circ} \mathrm{C}$ 焼結における S E M 観察 における液相の出現もすでに述べたとうりである。 しかしWB合金粉末の場合は, Photo.3に示したS E M に現れた液相はFig.3における白丸部の液相の出現に よるものである。

このような $2 つ の$ 液相の出現が焼結体の破断面に 認められるかどうかを S E Mにより観察した。試料 は吸熱ピークを示す温度の前後で焼結したあとの破 断面を調べた。その結果をPhoto.4に示す。1250 。Cにおいては 3 種頪の破面にはまだ異形状の気孔が 残存している。また粉末の接合に関しては，(b)の $\mathrm{TiB}_{2}$ 合金粉末の場合が他に較べて接合の進行が少な い。よってこれに起因して相対密度が低いと言える。 


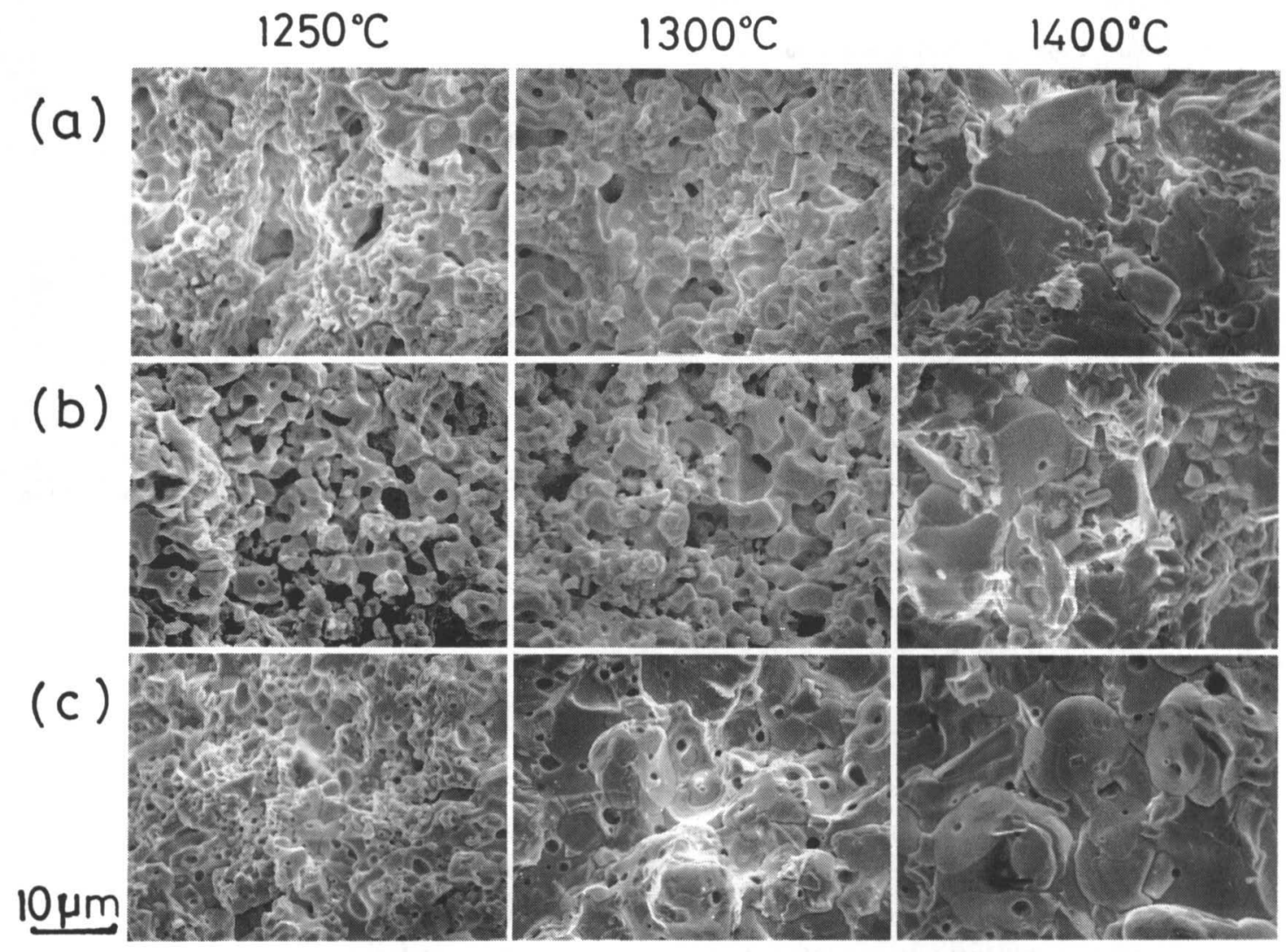

Photo.4 SEM microstructures at fracture surface of Mo powder compacts sintered at $1250^{\circ} \mathrm{C}, 1300^{\circ} \mathrm{C}$ and $1400^{\circ} \mathrm{C}$. (a):Mo-5wt\%Ni-10wt\%CrB powder compact,(b):Mo-5wt\%Ni-10wt\%TiB 2 powder compact, (c) :Mo-5wt\%Ni-10wt\%WB powder compact.

(a)のCrB合金粉末および(c)のWB合金粉末の場合は粉 末の接合が進み, 焼結が促進している。1300 $\mathrm{C}$ の破面は, 粉末の接合が進み粒子が成長している。 とくに(a)の破面は明瞭であり, 成長した粒子が粗大 化し形状に丸みがある。(b)の場合は(a)および(c)に 比較して部分的に粒子の成長が起こっている。気孔 は(b)の場合にまだ異形状のものが残つているが, 粒 子が成長している部分に残存しているものは閉じ込 められて球状化している。とくに(c)の場合に残って いる気孔は泡状である。粉末粒子の接合により, 気 孔がこのように閉じ込められている現象は明らかに 液相が生じたためと思われる。1 $400^{\circ}$ Cにおいて は (a), (b)および(c)の場合とも粒子が成長して粗大 化が進行し液相焼結を呈している。
Mo圧粉体に 3 種類のほう化合金粉末およびNi粉末 を添加して焼結したところ，つぎの結論が得られた。 1）３種類のほう化合金粉末をそれそれ添加した場 合, 相対密度はわずかに上昇する。添加したほう化 合金粉末の分解はない。

2) Ni粉末を同時に添加した場合は, 焼結温度が上 昇するとともに相対密度は大きく向上し，とくにWB 合金粉末の場合は顕著である。

3 ）Ni粉末を同時に添加して焼結した場合にはいず れも液相が出現し，このため焼結が促進すると考え られる。

4) D T A曲線の $2 つ の$ 吸熱ピークは液相の出現に よるものであると考えられる。低温側に生じる液相 はマトリックス中に局部的にわずかに生じているた め遷移的液相と称される一時的に出現する液相であ ると思われる。高温側に生じる液相は溶融によるも 
のである。

5) Ni粉末を同時に添加した場合，WB合金粉末は化 合物固有の分解温度より低い温度で分解する。しか し他のほう化合金粉末の分解は認められなかった。

竧 辞

本研究を推進するにあたつて，試料のご提供をい ただいた日本タングステン（株）殿さらにE P M A による分析にご協力願った熊本大学工学嘰器研究セ ンター宇藤様各位に心から感謝致します。

\section{文献}

1)坂本：粉体およひ粉末治金, 38(1991)839.
2)坂本：粉体および枌末治金，38(1991) 492 .

3)坂本：粉体およひ粉末治金，40(1993) 112 . 4)P.M.Hansen : Constitution of Binary Alloys, MCGRAW-HILL，(1958) 537，976，980.

5)坂本,下田：八代高専紀要, 14(1992) 17 . 6)J.M.Brranco and R.M. Warenchak : Int.J. of Refractory Metal \& Hard Materials.,(1989) 102.

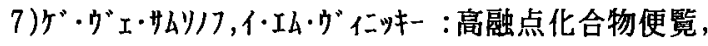
新日本鋳鍛造協会，（1977）170，171。

8)R.M.German : Progress in Powder Metallurgy, 42(1986) 235 .

9)三浦,本田,渡辺：粉体および粉末治金, 36(1989) 716 . 